\title{
The Determinants of Pakistan's Trade Balance: An ARDL Cointegration Approach
}

\author{
Waliullah", Mehmood Khan Kakar, Rehmatullah Kakar and \\ Wakeel Khan
}

\begin{abstract}
This article is an attempt to examine the short and long-run relationship between the trade balance, income, money supply, and real exchange rate in the case of Pakistan's economy. Income and money variables are included in the model in order to examine the monetary and absorption approaches to the balance of payments, while the real exchange rate is used to evaluate the conventional approach of elasticities (Marshall Lerner condition). The bounds testing approach to cointegration and error correction models, developed within an autoregressive distributed lag (ARDL) framework is applied to annual data for the period 1970 to 2005 in order to investigate whether a long-run equilibrium relationship exists between the trade balance and its determinants. Additionally, variance decompositions (VDCs) and impulse response functions (IRFs) are used to draw further inferences. The result of the bounds test indicates that there is a stable long-run relationship between the trade balance and income, money supply, and exchange rate variables. The estimated results show that exchange rate depreciation is positively related to the trade balance in the long and short run, consistent with the Marshall Lerner condition. The results provide strong evidence that money supply and income play a strong role in determining the behavior of the trade balance. The exchange rate regime can belp improve the trade balance but will have a weaker influence than growth and monetary policy.
\end{abstract}

Keywords: Trade balance, ARDL, exchange rate, money supply, Pakistan.

JEL Classification: F10, F12, C15, C22.

\footnotetext{
* Waliullah is a PhD candidate at the Graduate School of Economics and Management, Tohoku University, Sendai, Japan.

** Mehmood Khan Kakar, Rehmatullah Kakar, and Wakeel Khan are MPhil students at the Applied Economics Research Center, University of Karachi.
} 


\section{Introduction}

A change in exchange rate policy to improve external competitiveness has now become the focal point of any adjustment effort. It is believed that a nominal devaluation will result in expenditure switching, increased production of tradable goods and services, higher exports and an improvement of the country's external accounts. Traditional stabilization packages and especially their devaluation component have come under attack in recent studies. It has been argued that devaluation can be counterproductive because exports and imports are relatively insensitive to price and exchange rate changes, especially in developing countries. If the price elasticities of imports and exports are sufficiently low, the trade balance expressed in domestic currency may worsen. Grubel (1976) has argued that a country's persistent payment imbalances can be due only to faulty monetary policy and cannot be corrected by either devaluation (exchange rate policy) or the use of fiscal policy. Similarly, Miles (1979) shows that devaluation does not improve the trade balance but improves the balance of payments. This result implies that the improvement comes through the capital account. He therefore concludes that the devaluation mechanism involves only a portfolio stock adjustment and is essentially monetary in nature.

Furthermore, there is a time lag before the trade balance improves following a currency depreciation. The short- and long-run effects on the trade balance of currency depreciation are different. Initially, the trade balance deteriorates after depreciation and then starts to improve until it reaches its long-run equilibrium. The time path that the trade balance follows generates a J-curve.

However, despite popular belief that depreciation can improve the trade balance, empirical work tends to suggest mixed results. Among 30 countries studied, Rose (1990) finds that the impact of devaluation on the trade balance is insignificant for 28 countries, while one country shows a negative impact. He concludes that devaluation does not necessarily lead to an increase in the trade balance. If valid, the issue of whether or not the trade balance will improve after devaluation becomes more important. These results have important policy implications. If exchange rate (devaluations) do not improve the trade balance, then the various stabilization packages that include some exchange rate realignment cannot be justified.

As a developing country, In Pakistan imports exceed exports due to which the country faces a large trade deficit every year. Similarly, it reported a balance of trade deficit equivalent to USD1278.4 million in 
April 2010. Since 1982, the Pakistan rupee has been characterized by a managed float; the rupee was pegged to a basket of currencies with the US dollar being the main anchor currency. In 1998, to alleviate the financial crisis in Pakistan, the authorities adopted a multiple exchange rate system, which comprised an official rate (pegged to the US dollar), a floating interbank rate (FIBR), and a composite rate (combining the official and FIBR rates). With the economy recovering from the crisis in 1999, the three exchange rates were unified and pegged to the US dollar within a certain band. This band was removed in 2000. Since July 2000, Pakistan has maintained a floating rate, although central bank intervention continues, and therefore the issues of real depreciation to correct the trade balance remain controversial.

The main objective of the study is to examine the validity of the argument that exchange rate devaluation improves the trade balance. In addition, it attempts to test the short- and long-run empirical relevance of the absorption and monetarist approaches by incorporating the variables of income and money supply in the model. Variance decomposition and impulse response analyses are carried out to observe the direction, magnitude, and persistence of the trade balance in relation to variations in policy variables such as the real exchange rate, income, and money supply. Pakistan provides an ideal opportunity to examine this issue as in recent years its trade balance has deteriorated considerably. It also pursued a fixed exchange rate policy until January 1982. Since then, Pakistan has pursued a managed floating exchange rate policy to maintain external competitiveness. The subject matter concerns the various channels through which the trade balance can be improved.

The remainder of this paper is organized as follows. Sections 2 and 3 discuss briefly the relevant literature and various theories of the balance of payments from three different views, namely the elasticity, absorption, and monetary approaches. Section 4 presents the econometric methodology and data. Section 5 discusses the empirical results, and Section VI provides the main conclusions and policy implications.

\section{Literature Review}

Defining the exchange rate policy is one of the most important issues in the response of the trade balance to the real exchange rate (RER). The impacts of currency depreciation on a country's trade balance have been extensively examined in the empirical literature in the context of the Marshall Lerner condition and the J-curve theory. According to the former, currency devaluation improves the trade balance only if the sum of the 
absolute values of import and export demand price elasticities exceeds unity. However, due to lag dynamics, the structure can worsen in the short run because of the inelastic demand for imports and exports in the immediate aftermath of an exchange rate change. Recently, numerous papers have tested the Marshall Lerner condition and J-curve. Bahmani-Oskooee and Niroomand (1999) have tested the Marshall Lerner condition for 30 developed and developing countries for the period 1960-1992. Gomes and $\mathrm{Paz}$ (2005) and Tsen (2006) find the existence of a long-run relationship between the trade balance, RER, foreign and domestic income for Brazil and Malaysia during 1965-2002. Bahamani-Oskooee and Ratha (2004) provide a good survey on the Marshal Lerner condition and J-curve, showing inconclusive results for this issue.

Rose (1991) has examined the empirical relationship between the real effective exchange rate and trade balance for five major OECD countries. He finds that the exchange rate is a statistically insignificant determinant of the balance of trade. Similarly, Rose and Yellen (1989) do not find any significant relationship between the RER and balance of payments. They examine bilateral trade flows between the US and other OECD countries using quarterly data. Most studies relating the exchange rate to the trade balance have found weak statistical evidence of such a relationship, i.e., Greenwood (1984), Mahdavi and Sohrabian (1993), Rahman and Mustafa (1996), and Rahman et al. (1997). Himarios (1989) and Bahmani-Oskooee (2001) have found weak statistical evidence connecting exchange rate changes and the trade balance. Mahmud et al. (2004) suggest that, although the Marshal Lerner condition holds during fixed exchange rate periods, it is less likely to do so in flexible exchange rate periods. Furthermore, Singh (2002) finds that the RER and domestic income explain a significant influence while foreign income shows an insignificant impact on the trade balance in India. Singh's study also demonstrates a very significant effect $(+2.33)$ of the RER and domestic income $(-1.87)$ on the Indian trade balance.

Tavlas (2003) has reviewed issues surrounding the exchange rate, particularly types of exchange rate regimes. Mussa (2002) and Edwards (2002) provide synoptic reviews and analysis of the RER. They point out that exchange rate misalignment issues are very important in the exchange rate regime literature. In other words, the fundamental fluctuations of macroeconomic policies lead to the disequilibrium of the RER; if the nominal exchange rate remains fixed, the result is misalignment between the RER and the new equilibrium rate. Furthermore, various studies have explored and tried to identify effective exchange rate regimes in a world increasingly characterized by high capital flow mobility. Goldstein (1992) proposes that countries choose 
from among a broad spectrum of exchange rate arrangements and says that exchange rate commitments should be tailored to the characteristics and circumstances of individual countries.

A wide range of papers have tested the monetary and absorption approaches to balance of payments. Lardy (1996), Zhang, et a1. (1999), and Liu, et al. (2001) have shown that foreign-invested firms have contributed significantly to China's impressive export expansion and economic growth. Using panel data at the provincial level from 1986 to 1997, Tse (1997) has shown that inward FDI has a positive effect on provincial manufacturing export performance. However, Sun (2001) argues that the role of FDI changes across regions in China. FDI has a positive and significant impact on exports from the coastal region to the central region and positive but statistically insignificant impact on export performance in the western region.

A study on ASEAN-5 countries by Kim-sen Liew et al. (2003) has shown that the trade balance in these countries is affected by real money rather than by the nominal exchange rate; it concludes that the role of exchange rate changes in trade balances has been exaggerated. However, very few attempts have been made to incorporate other views on the balance of trade/balance of payments analysis or to test these other views empirically. Duasa (2007) examines the short- and long-run relationships between trade balance, RERs, income, and money supply in the case of Malaysia. He includes income and money variables in his model in order to examine monetary and absorption approaches to the balance of payments beside the conventional elasticity approach, using exchange rates. Using the ARDL cointegration approach, he finds a positive but statistically insignificant relationship between the trade balance and exchange rate. The money supply and domestic income have a strong negative and positive impact on the trade balance (consistent with the monetary approach and absorption approach, respectively). The findings also suggest that the Marshall Lerner condition does not hold in the long run for Malaysia and that, policy wise, the Malaysian trade balance/balance of payments should be viewed from the absorption and monetary approaches.

\section{Theoretical Framework}

There are a number of theoretically distinct approaches to predicting the outcome of policy changes on the balance of payments. The elasticity approach describes the effects of changes in the exchange rate. This view is rooted in a static and partial equilibrium approach to the balance of 
payments that is well known as the elasticity approach ${ }^{1}$ (Bickerdike, 1920; Robinson, 1947; Metzler, 1948). It states that, starting from a balanced trade situation, devaluation will improve the balance of payments if the sum of the price elasticities (a measure of how much demand changes in response to a price change) of domestic and foreign demand for imports is larger than 1. Devaluation always improves the balance of payments if this condition is satisfied-although it is not a necessary condition of such improvement. The essence of this view is the substitution effects in consumption and production induced by the relative price (domestic versus foreign) changes caused by a devaluation. In particular, the Marshall Lerner condition states that, for a positive effect of devaluation on the trade balance, and implicitly for a stable exchange market, the absolute values of the sum of the demand elasticities for exports and imports must exceed unity. Assuming that the Marshall Lerner condition is met, when the exchange rate is above the equilibrium there is excess supply of foreign exchange and when the exchange rate is below the equilibrium there is excess demand for foreign exchange.

The absorption approach ${ }^{2}$ to the balance of payments emerged at the beginning of 1950s when authors such as Harberger (1950), Meade (1951), and Alexander $(1952,1959)$ shifted the focus of economic analysis to the balance of payments. This approach is in some respects an alternative to the elasticity approach. It states that a country's trade balance will improve if its output of goods and services increases by more than its absorption-the expenditure by domestic residents of goods and services. This approach takes a more macroeconomic view of the balance-of-payments question and looks at production and expenditure for the economy as a whole. It argues that currency devaluation will be successful only if the gap between domestic output and expenditure widens. The theory has been criticized, however, from a number of directions: first, for ignoring the inflationary effects of devaluation; second, for being inappropriate if the economy is at full employment, in which case output cannot increase; third, for completely ignoring monetary factors; and fourth, for dealing with the balance of trade without taking account of capital movements.

A different approach, the monetarist approach $^{3}$ (Polak, 1957; Hahn, 1959; Pearce, 1961; Prais, 1961; Munde11, 1968, 1971) of the balance of payments emerged at the end of 1950s. This approach emphasizes the interaction between the demand and supply of money to determine the

\footnotetext{
${ }^{1}$ See Appendix 1 for further detail.

${ }^{2}$ See Appendix 2 for further detail.

${ }^{3}$ See Appendix 3 for further detail.
} 
overall balance of payments position of the economy. Since, for any economy, the monetary base equals the sum of the domestic value of international reserves and the domestic asset holdings of monetary authorities, a change in international reserves is reflected in the change in the money supply. In very simple terms, if people demand more money than that being supplied by the central bank, then the excess demand for money will be satisfied by inflows of money from abroad. In this case, the trade balance will improve. On the other hand, if the central bank is supplying more money than is demanded, the excess supply of money is eliminated by outflows of money to other countries and this will worsen the trade balance.

The three different views presented above demonstrate that a country's balance of payments will be affected by changes in the domestic income level, money supply, and exchange rate. With regard to these different views, the present study develops a model that incorporates simultaneously all three approaches and uses it to analyze Pakistan's trade balance. ${ }^{4}$ The reason for incorporating all three approaches in a single equation model is to verify their empirical relevance and validity and minimize the residual unexplained variation in the trade balance model.

\section{Methodology and Data}

The variable in this study, the trade balance, is measured as the ratio of export value $(\mathrm{X})$ to import value $(\mathrm{M})$. The ratio of $\mathrm{X}$ to $\mathrm{M}$ (i.e., $\mathrm{X} / \mathrm{M}$ ) or its inverse has been widely used in many empirical investigations of trade balance-exchange rate relationship, such as Bahmani-Oskooee and Brooks (1999), Lal and Lowinger (2001), and Onafowora (2003). This ratio is preferable because it is not sensitive to the unit of measurement and can be interpreted as the nominal or real trade balance (Bahmani-Oskooee, 1991). Gross domestic product (GDP) is used as a proxy for income and M3 for money supply. All variables are expressed in natural logarithms in order to estimate their elasticities.

The traditional approach to determining long run and short run relationships among variables has been to use the standard Johanson Cointegration and VECM framework, but this approach suffers from serious flaws as discussed by Pesaran et al. (2001). We adopt the autoregressive distributed lag (ARDL) framework popularized by Pesaran and Shin (1995, 1999), Pesaran, et a1. (1996), and Pesaran (1997) to establish the direction of causation between variables. The ARDL method yields consistent and robust results both for the long-run and short-run relationship between

\footnotetext{
${ }^{4}$ This type of model has been estimated for the Malaysian trade balance by Duasa (2007).
} 
trade balance and various policy variables. This approach does not involve pretesting variables, which means that the test for the existence of relationships between variables is applicable irrespective of whether the underlying regressors are purely $I(0)$, purely $I(1)$, or a mixture of both.

In order to obtain robust results, we utilize the ARDL approach to establish the existence of long-run and short-run relationships. ARDL is extremely useful because it allows us to describe the existence of an equilibrium/relationship in terms of long-run and short-run dynamics without losing long-run information. The ARDL approach consists of estimating the following equation.

$$
\begin{aligned}
& \Delta \ln (T B)_{t}=\alpha_{0}+\sum_{i=1}^{n} \beta_{i} \Delta \ln (T B)_{t-i}+\sum_{i=0}^{n} \delta_{i} \Delta \ln (G D P)_{t-i}+\sum_{i=0}^{n} \eta_{i} \Delta \ln (M 3)_{t-i} \\
& +\sum_{i=0}^{n} \psi_{i} \Delta \ln (E X)_{t-i}+\lambda_{1} \ln (T B)_{t-1}+\lambda_{2} \ln (G D P)_{t-1}+\lambda_{3} \ln (M 3)_{t-1} \\
& +\lambda_{4} \ln (E X)_{t-1}+\varepsilon_{i}
\end{aligned}
$$

The first part of the equation with $\beta_{i}, \delta_{i}, \eta_{i}$ and $\psi_{i}$ represents the short-run dynamics of the model whereas the parameters $\lambda_{1}, \lambda_{2}, \lambda_{3}$ and $\lambda_{4}$ represents the long-run relationship. The null hypothesis of the model is

$$
\begin{array}{ll}
\mathrm{H}_{0}: & \lambda_{1}=\lambda_{2}=\lambda_{3}=\lambda_{4}=0 \text { (there is no long-run relationship) } \\
\mathrm{H}_{1}: & \lambda_{1} \neq \lambda_{2} \neq \lambda_{3} \neq \lambda_{4} \neq 0
\end{array}
$$

We start by conducting a bounds test for the null hypothesis of no cointegration. The calculated F-statistic is compared with the critical value tabulated by Pesaran (1997) and Pesaran et al. (2001). If the test statistics exceeds the upper critical value, the null hypothesis of a no long-run relationship can be rejected regardless of whether the under lying order of integration of the variables is 0 or1. Similarly, if the test statistic falls below a lower critical value, the null hypothesis is not rejected. However, if the test statistic falls between these two bounds, the result is inconclusive. When the order of integration of the variables is known and all the variables are I(1), the decision is made based on the upper bound. Similarly, if all the variables are $I(0)$, then the decision is made based on the lower bound.

The ARDL methods estimates $(p+1)^{\mathrm{k}}$ number of regressions in order to obtain the optimal lag length for each variable, where $p$ is the maximum number of lags to be used and $\mathrm{k}$ is the number of variables in the equation. 
In the second step, if there is evidence of a long-run relationship (cointegration) among the variables, the following long-run model (Equation 2 ) is estimated,

$$
\begin{aligned}
& \ln (T B)_{t}=\alpha_{1}+\sum_{i=1}^{n} \beta_{i} \ln (T B)_{t-i}+\sum_{i=0}^{n} \delta_{i} \ln (G D P)_{t-i}+\sum_{i=0}^{n} \psi_{i} \ln (M 3)_{t-i} \\
& +\sum_{i=0}^{n} \eta_{i} \ln (E X)_{t-i}+\varepsilon i
\end{aligned}
$$

If we find evidence of a long-run relationship, we then estimate the error correction model (ECM), which indicates the speed of adjustment back to long-run equilibrium after a short-run disturbance. The standard ECM involves estimating the following equation.

$$
\begin{aligned}
& \Delta \ln (T B)_{t}=\gamma_{1}+\delta_{1}(E C M)_{t-1}+\sum_{\mathrm{i}=1}^{\mathrm{n}} \alpha_{i} \Delta \ln (T B)_{t-i}+\sum_{\mathrm{i}=0}^{\mathrm{n}} \beta_{i} \Delta \ln (G D P)_{t-i} \\
& +\sum_{i=0}^{\mathrm{n}} \eta_{i} \Delta \ln (M 3)_{t-i}+\sum_{i=0}^{n} \psi_{i} \Delta \ln (E X)_{t-i}+\varepsilon_{i}
\end{aligned}
$$

To ascertain the goodness of fit of the ARDL mode1, diagnostic and stability tests are conducted. The diagnostic test examines the serial correlation, functional form, normality, and hetroscedasticity associated with the model. The structural stability test is conducted by employing the cumulative residuals (CUSUM) and the cumulative sum of squares of recursive residuals (CUSUMSQ).

Furthermore, we simulate VDCs and IRFs for further inferences. VDCs and IRFs serve as tools for evaluating the dynamic interactions and strength of causal relations among variables in the system. The VDC indicates the percentages of a variable's forecast error variance attributable to its own innovations and innovations in other variables. Thus, from the VDC, we can measure the relative importance of the RER, income, and money fluctuations in accounting for fluctuations in the trade balance variable. Moreover, the IRF traces the directional responses of a variable to a one-standard deviation shock to another variable. This means that we can observe the direction, magnitude, and persistence of trade balance to variations in the RER, income, and money supply.

The variables in this study, trade balance (TB) and income (GDP), are taken from World Development Indicators. Data on money supply (M3) is taken from various issues of the Pakistan Economic Survey, while data on the real exchange rate $(\mathrm{EX})$ are collected from the International Financial Statistics database. The data are annual and spans the time period 1970 to 2005 . 


\section{Empirical Results}

Before testing the cointegration relationship, a test of order of integration for each variable using the Augmented Dickey-Fuller (ADF) and Phillips Perron (PP) tests are conducted. Even though the ARDL framework does not require the pre-testing of variables, the unit root test could help in determining whether or not the ARDL model should be used. The results in Table- 1 and 2 are the unit root test results of the Augmented Dickey-Fuller and Phillip Perron tests, respectively, showing that there is a mixture of $I(1)$ and $I(0)$ of underlying regressors and that, therefore, we can proceed with ARDL testing.

Trade balance (TB), gross domestic product (GDP) and money supply (M3) are integrated to the order of one I(1), while the real exchange rate (EX) is integrated to the order of zero $I(0)$.

Table-1: Unit-Root Estimation (ADF Test)

\begin{tabular}{llll}
\hline Variables & Lag 1 & Lag 2 & Lag 3 \\
\hline TB & -3.101 & -3.101 & -3.101 \\
$\Delta$ TB & $-5.243^{*}$ & $-3.677^{* *}$ & $-3.677^{* *}$ \\
GDP & -1.089 & -1.089 & -1.089 \\
$\Delta$ GDP & $-4.565^{*}$ & $-3.701^{* *}$ & $-4.565^{*}$ \\
M3 & -2.645 & -2.645 & -2.645 \\
$\Delta$ M3 & $-5.028^{*}$ & $-5.028^{*}$ & $-5.028^{*}$ \\
EX & $-3.221^{* * *}$ & $-3.221^{* * *}$ & $-3.221^{* * *}$ \\
$\Delta \mathrm{EX}$ & $-7.072^{*}$ & $-7.072^{*}$ & $-8.461^{*}$ \\
\hline
\end{tabular}

Notes: ${ }^{*}, * *, * * *$ represents significant at $1 \%, 5 \%$ and $10 \%$.

Table-2: Unit-Root Estimation (Philips Perron Test)

\begin{tabular}{llll}
\hline Variables & Lag 1 & Lag 2 & Lag 3 \\
\hline TB & -3.155 & -3.120 & -3.179 \\
$\Delta$ TB & $-6.186^{*}$ & $-6.240^{*}$ & $-6.258^{*}$ \\
GDP & -2.383 & -2.445 & -2.453 \\
$\Delta$ GDP & $-5.032^{*}$ & $-5.014^{*}$ & $-4.992^{*}$ \\
M3 & -0.996 & -1.116 & -1.227 \\
$\Delta$ M3 & $-4.507^{*}$ & $-4.523^{*}$ & $-4.544^{*}$ \\
EX & -3.186 & $-3.275^{* * *}$ & $-3.345^{* * *}$ \\
$\Delta \mathrm{EX}$ & $-7.006^{*}$ & $-6.996^{*}$ & $-7.000^{*}$ \\
\hline
\end{tabular}

Notes: ${ }^{*}, * * * * *$ represents significant at $1 \%, 5 \%$ and $10 \%$. 
Now we turn to the ARDL approach to determining long-run relationships as mentioned in Table-4. The main assumption of ARDL is that the variables in model are cointegrated to the order of $I(0)$ or $I(1)$ or both. This lends support to the implementation of bounds testing, which is a threestep procedure. In the first step, we select a lag order on the basis of the Schwarz-Bayesian criteria (SBC) because the computation of F-statistics for cointegration is very sensitive to lag length. The lag length that minimizes SBC is 1 . The calculated $F$-statistic $\left(F_{\text {statistic }}=4.233\right)$ is higher than the upper bound critical value at a 5\% level of significance (3.67), using a restricted intercept and no trend as reported by Pesaran et al. (2001). This implies that the null hypothesis of no cointegration is rejected at $5 \%$ and that, therefore, there is a cointegrating relationship among the variables.

The empirical results of the long-run model obtained by normalizing the trade balance are presented in Table-3 (ARDL $(0,0,1,0)$ selected based on the SBC and Table-4 (ARDL $(1,0,1,0)$ selected based on the Akaike information criterion $[\mathrm{AIC}]$ ).

Table-3: Estimated Long Run Coefficients using the ARDL Approach

ARDL $(0,0,1,0)$ based on Schwarz Bayesian Criterion

Dependent Variable: (TB)

\begin{tabular}{lccc}
\hline Variables & Coefficient & t-Values & Prob-Values \\
\hline Constant & -7.706 & -5.932 & {$[0.000]$} \\
$\mathrm{GDP}_{\mathrm{t}}$ & 1.562 & 4.118 & {$[0.000]$} \\
$\mathrm{M} 3_{\mathrm{t}}$ & -0.367 & -3.267 & {$[0.003]$} \\
$\mathrm{M} 3_{\mathrm{t}-1}$ & -0.889 & -3.042 & {$[0.005]$} \\
$\mathrm{EX}_{\mathrm{t}}$ & 0.560 & 3.385 & {$[0.002]$} \\
$\mathrm{R}^{2}=0.901$ & & F-Statistics $(4,29)=65.923[0.000]$ \\
Adjusted- $\mathrm{R}^{2}=0.887$ & & Durbin-Watson Stat $=1.683$ \\
\hline
\end{tabular}


Table-4: Estimated Long Run Coefficients using the ARDL Approach

ARDL $(1,0,1,0)$ based on Akaike Information Criterion

Dependent Variable: (TB)

\begin{tabular}{llcc}
\hline Variables & Coefficient & t-Values & Prob-Values \\
\hline Constant & -6.132 & -3.710 & {$[0.001]$} \\
$\mathrm{TB}_{\mathrm{t}-1}$ & 0.252 & 1.819 & {$[0.040]$} \\
$\mathrm{GDP}_{\mathrm{t}}$ & 1.302 & 3.187 & {$[0.004]$} \\
$\mathrm{M} 3_{\mathrm{t}}$ & -0.242 & -2.198 & {$[0.036]$} \\
$\mathrm{M} 3_{\mathrm{t}-1}$ & -0.691 & -2.198 & {$[0.036]$} \\
$\mathrm{EX}_{\mathrm{t}}$ & 0.445 & 2.488 & {$[0.019]$} \\
$\mathrm{R}^{2}=0.908$ & & F-Statistics $(5,28)=55.576[0.000]$ \\
Adjusted-R ${ }^{2}=0.892$ & & Durbin-Watson Stat $=2.007$ \\
\hline
\end{tabular}

The results indicate that the domestic income level as measured by GDP is an important determinant of trade balance. Every 1\% increase in real income yields an average $1.56 \%$ improvement in the trade balance (SBC selection criterion results) and a $1.30 \%$ improvement under the AIC selection criterion results. Similarly, the sign of the money supply variable is consistent with the monetary approach to trade balance. The theory indicates that a rise in domestic income increases the demand for money and will therefore increase exports and improve the trade balance. Also, a fall in domestic money supply improves the trade balance since foreigners send their money domestically for more goods and services. The impact of the exchange rate on the trade balance is positive and statistically significant. It suggests that the Marshall-Lerner condition holds in the long run in the case of Pakistan. The devaluation/depreciation of domestic currency by $1 \%$ on average improves the trade balance by $0.56 \%$ and $0.44 \%$ in the long run as suggested by the SBC selection criterion and AIC selection criterion respectively. It indicates that the sum of elasticities of exports and imports exceeds unity in the long run and that devaluation/depreciation improves the trade balance. 
Table-5: Error Correction Representation for the selected ARDL-Model

\begin{tabular}{|c|c|c|c|}
\hline \multicolumn{4}{|c|}{$\begin{array}{l}\text { ARDL }(1,0,1,0) \text { based on Akaike Infor } \\
\text { Dependent Variable: } \Delta(\mathrm{TB})_{t}\end{array}$} \\
\hline Variables & Coefficients & t-Values & Prob-Values \\
\hline Constant & -6.132 & -3.740 & {$[0.001]$} \\
\hline$\Delta \mathrm{TB}_{\mathrm{t}-1}$ & 0.251 & 1.819 & {$[0.040]$} \\
\hline$\Delta \mathrm{GDP}_{\mathrm{t}}$ & 1.302 & 3.187 & {$[0.003]$} \\
\hline$\Delta \mathrm{M} 3_{\mathrm{t}}$ & -0.789 & -2.978 & {$[0.004]$} \\
\hline$\Delta \mathrm{M}_{\mathrm{t}-1}$ & 0.242 & 0.821 & {$[0.418]$} \\
\hline$\Delta \mathrm{EX}_{\mathrm{t}}$ & 0.445 & 2.488 & {$[0.019]$} \\
\hline $\mathrm{ECM}_{\mathrm{t}-1}$ & -0.749 & -4.529 & {$[0.000]$} \\
\hline \multicolumn{2}{|c|}{ R-Squared $=0.449$} & \multicolumn{2}{|c|}{ Akaike Info Criterion $=16.446$} \\
\hline \multicolumn{2}{|c|}{ Adjusted $\mathrm{R}^{2}=0.351$} & \multicolumn{2}{|c|}{ Schwarz Criterion $=11.867$} \\
\hline \multicolumn{2}{|c|}{ Durbin-Watson Stat $=2.007$} & stic $(4,29$ & $5.713[0.002]$ \\
\hline
\end{tabular}

The results of the ECM for trade balance are presented in Table-5. Most of the coefficients in the short run are significant, except for the lag difference of money supply. The positive sign of the coefficient of income variable does not support the Keynesian view that income increases will encourage citizens to buy more imported goods and thus worsens the trade balance. However, this impact could only be observed in the short run. Money supply has a negative and statistically significant impact on the trade balance and the magnitude of the impact is much higher than that of the long-run impact, indicating that the impact of change in money supply is much stronger in the short run. However, the impact of the exchange rate on the trade balance is almost the same in the long run and short run. Furthermore, the exchange rate has a positive and highly significant effect on the balance of trade. This implies that the Marshall-Lerner condition holds even in the short run.

We apply a number of diagnostic tests to the ECM, finding no evidence of serial correlation, heteroskedasticity and ARCH (Autoregressive Conditional Heteroskedasticity) effect in the disturbances. The model also passes the Jarque-Bera normality test which suggests that the errors are normally distributed. 
The significance of an error correction term (ECT) shows causality in at least one direction. The lagged error term $\left(\mathrm{ECM}_{\mathrm{t}-1}\right)$ in our results is negative and highly significant. The coefficient of -0.74884 indicates a high rate of convergence to equilibrium, which implies that deviation from the long-term equilibrium is corrected by $74.88 \%$ over each year. The lag length of the short-run model is selected on basis of the AIC.

From an estimated VAR, we compute VDCs and IRFs, which serve as tools for evaluating the dynamic interactions and strength of causal relations among variables in the system. In simulating VDCs and IRFs, it should be noted that VAR innovations may be contemporaneously correlated. This means that a shock in one variable may work through the contemporaneous correlation with innovations in other variables. The responses of a variable to innovations in another variable of interest cannot be adequately represented since isolated shocks to individual variables cannot be identified due to contemporaneous correlation (Lutkepoh1, 1991). Therefore, we use Cholesky factorization which orthogonalizes the innovations as suggested by Sims (1980) to solve this identification problem. The strategy requires a prespecified causal ordering of the variables. The results from VDC and IRFs may be sensitive to the variables' ordering unless the error terms' contemporaneous correlations are low. The ordering of variables suggested by Sims (1980) starts with the most exogenous variable in the system and ends with the most endogenous variable.

To see whether the ordering could be a problem, the contemporaneous correlations of VAR error terms are checked and displayed in Table-6. The results show that there are high correlations between trade balance and the RER, between RERs and M3, and between GDP and M3. Other correlations are mostly less than 0.2 . Based on this, we can arrange the variables according to the following order: M3, GDP, EX, and TB.

VDC is an alternative method to IRFs for examining the effects of shocks on dependent variables. It shows how much of the forecast error variance for any variable in a system is explained by innovations to each explanatory variable over a series of time horizons. Usually, own series shocks explain most of the error variance, although the shock will also affect other variables in the system. From Table-6, the VDC substantiates the significant role played by GDP, M3, and EX in accounting for fluctuations in the Pakistani TB. At the one-year horizon, the fraction of Pakistan's trade balance forecast error variance attributable to variations in income, money supply, and RER are 41.64\%, $12.2 \%$, and $1.28 \%$, respectively. The explanatory power of all variables increases further at the 4-year horizon, but the percentage of trade balance forecast variance explained by 
innovations in $\mathrm{EX}$ is smaller than explained by innovations in other variables. However, the portion of trade balance variations explained by all explanatory variables increases continuously over longer horizons, for which the percentage of forecast variances in the trade balance is largely explained by innovations in GDP among other explanatory variables as it maintains higher percentages than the others.

Looking along the main diagonal, the results reveal that the own shock is relatively high for GDP and TB, at $96.24 \%$ and $49.82 \%$, respectively. This implies the exogeneity of GDP and TB in VDCs, as after the first year after the shock, the variance appears to be less explained by innovations in other explanatory variables. On the other hand, the results shows that the percentage of variance explained by own shocks for M3 and EX are similar to $24.89 \%$ and $26.91 \%$, respectively. 
Table-6

\begin{tabular}{|c|c|c|c|c|}
\hline \multicolumn{5}{|c|}{ \% of Forecast Variances Explained by Innovation in } \\
\hline Horizon & TB & GDP & M3 & $E \boldsymbol{X}$ \\
\hline \multicolumn{5}{|c|}{ (a) Variance Decomposition of TB } \\
\hline 1 & 66.459 & 41.64903 & 12.201 & 1.281 \\
\hline 4 & 49.817 & 38.023 & 11.932 & 1.061 \\
\hline 9 & 49.817 & 38.023 & 11.932 & 1.061 \\
\hline 15 & 49.817 & 38.023 & 11.932 & 1.061 \\
\hline 24 & 49.817 & 38.023 & 11.932 & 1.061 \\
\hline \multicolumn{5}{|c|}{ (b) Variance Decomposition of GDP } \\
\hline 1 & 2.023 & 97.976 & 6.829 & 0.938 \\
\hline 4 & 3.227 & 96.242 & 7.073 & 0.941 \\
\hline 9 & 3.224 & 96.242 & 7.073 & 0.941 \\
\hline 15 & 3.224 & 96.242 & 7.073 & 0.941 \\
\hline 24 & 3.224 & 96.242 & 7.073 & 0.941 \\
\hline \multicolumn{5}{|c|}{ (c) Variance Decomposition of M3 } \\
\hline 1 & 6.263 & 71.508 & 25.488 & 0.578 \\
\hline 4 & 5.994 & 66.459 & 24.891 & 0.617 \\
\hline 9 & 5.722 & 66.459 & 24.891 & 0.617 \\
\hline 15 & 5.722 & 66.459 & 24.891 & 0.617 \\
\hline 24 & 5.722 & 66.459 & 24.891 & 0.617 \\
\hline \multicolumn{5}{|c|}{ (d) Variance Decomposition of EX } \\
\hline 1 & 0.874 & 14.286 & 3.018 & 29.450 \\
\hline 4 & 4.153 & 8.546 & 2.948 & 26.906 \\
\hline 9 & 4.153 & 8.546 & 2.948 & 26.906 \\
\hline 15 & 4.153 & 8.546 & 2.948 & 26.906 \\
\hline 24 & 4.153 & 8.546 & 2.948 & 26.906 \\
\hline
\end{tabular}


Figure 1: Impulse Response Functions

Response to Cholesky One S.D. Innovations \pm 2 S.E

Response of $\mathrm{D}(\mathrm{TB})$ to $\mathrm{D}(\mathrm{TB})$

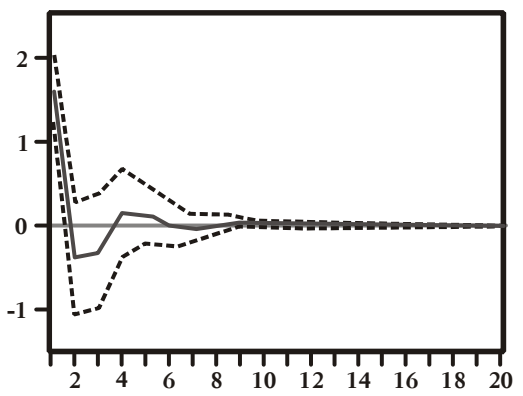

Response of $\mathrm{D}(\mathrm{EX})$ to $\mathrm{D}(\mathrm{M} 3)$

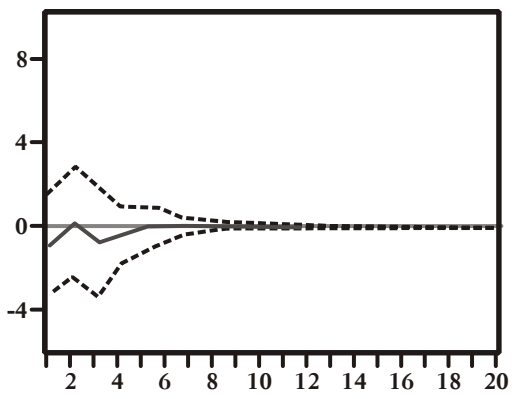

Response of $\mathrm{D}(\mathrm{TB})$ to $\mathrm{D}(\mathrm{M} 3)$

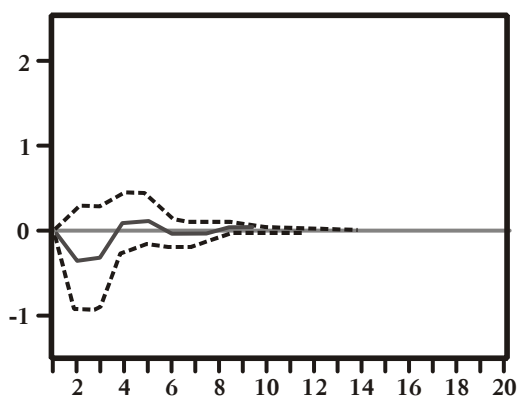

Response of D(GDP) to $\mathrm{D}(\mathrm{TB})$

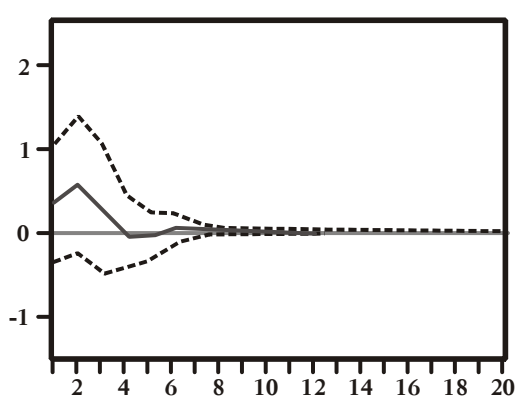

Response of $\mathrm{D}(\mathrm{TB})$ to $\mathrm{D}(\mathrm{GDP})$

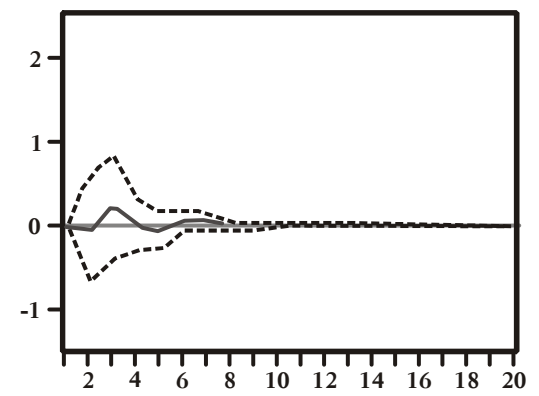

Response of $\mathrm{D}(\mathrm{EX})$ to $\mathrm{D}(\mathrm{EX})$

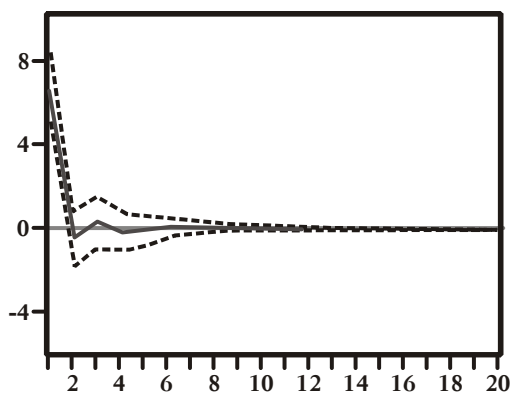

Response of $\mathrm{D}(\mathrm{TB})$ to $\mathrm{D}(\mathrm{EX})$

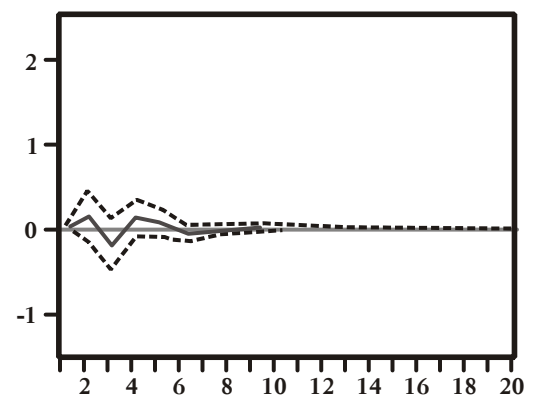

Response of D(GDP) to D(GDP)

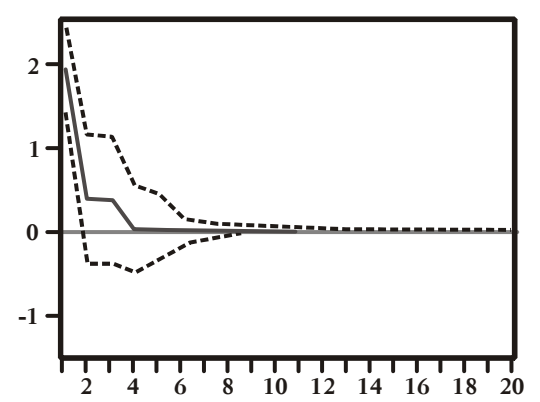



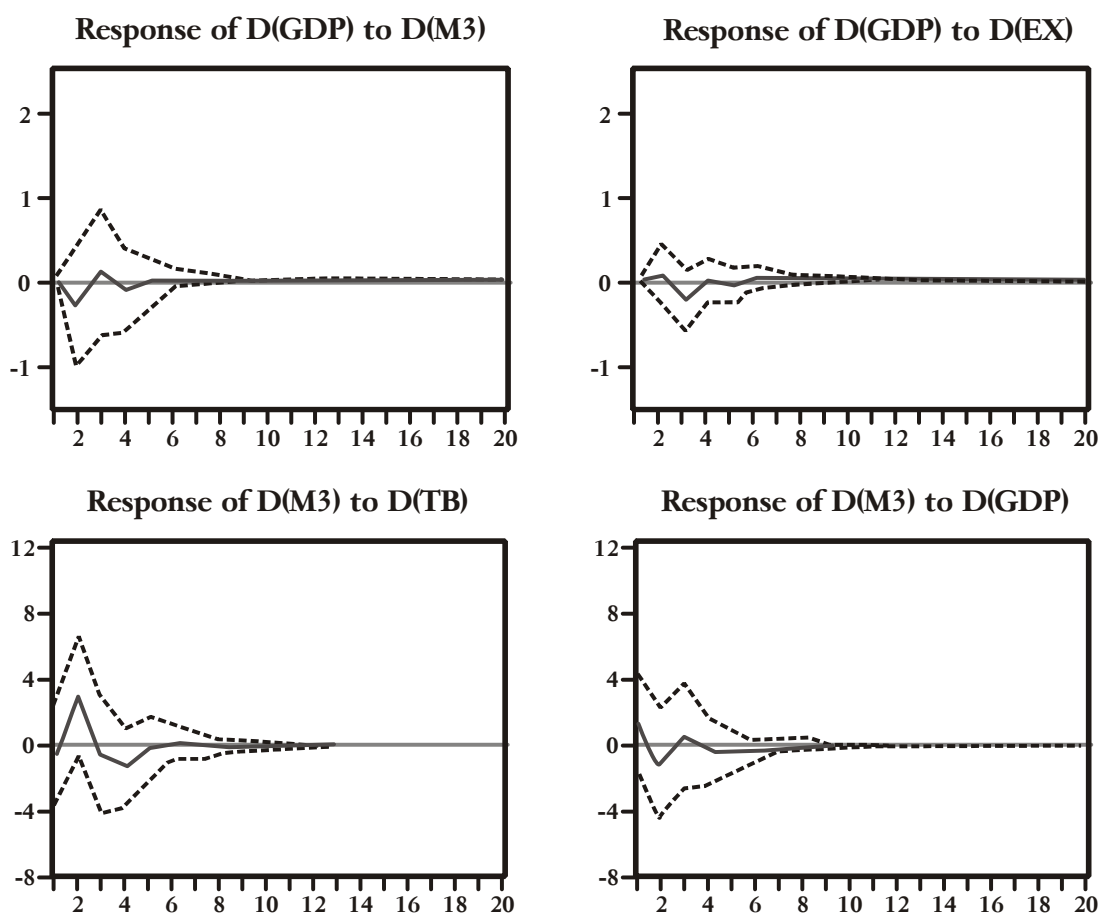

Response of $\mathrm{D}(\mathrm{M} 3)$ to $\mathrm{D}(\mathrm{M} 3)$

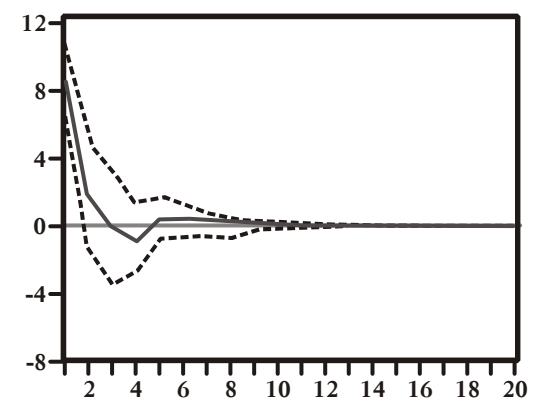

Response of D(M3) to D(EX)

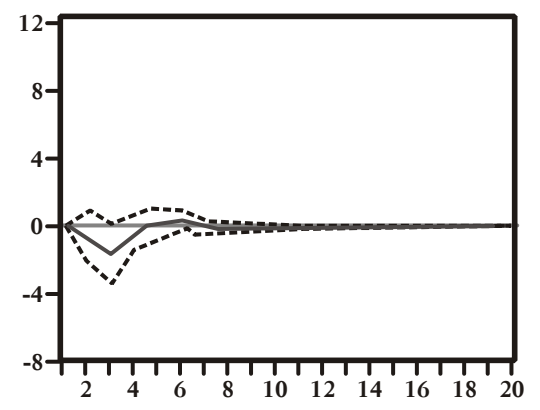

Response of $\mathrm{D}(\mathrm{EX})$ to $\mathrm{D}(\mathrm{TB})$

Response of D(EX) to D(GDP)
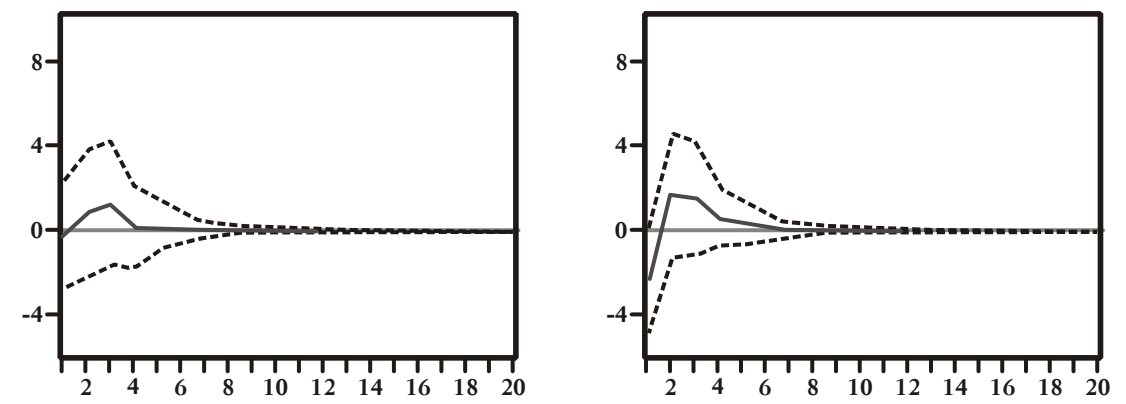


\section{Conclusion}

This study reviews and tests the three major alternative theories of balance of payments adjustments. These theories are the elasticities and absorption approaches (associated with Keynesian theory), and the monetary approach. In the elasticities and absorption approaches, the focus is on the trade balance with unemployed resources. In the monetary approach, on the other hand, the focus is on the balance of payments with full employment. The monetary approach emphasizes the role of demand for and supply of money in the economy. Thus, the present study is an attempt to assess the three major approaches simultaneously in a dynamic model for the Pakistani balance of trade.

The method used is a bounds testing approach to cointegration, developed within an ARDL framework to investigate the existence of a longrun equilibrium relationship between trade balance, income, money supply and exchange rates. The results provide strong evidence that money supply and income play a stronger role in determining the long run as well as short run behavior of the trade balance in Pakistan as compared to the exchange rate, since money supply and income level have a much stronger impact on trade balance. The policy implication is that difficulties in the trade balance should be corrected through policies for income or growth as well as money supply. Although the exchange rate regime can improve the trade balance, it has a weaker influence than monetary policy. 


\section{Appendix-1}

\section{Elasticities Approach to the Balance of Trade}

The effect of exchange rates on international trade will depend on the elasticities of demand and supply for goods and services.

Elasticity of Demand: $e_{d}=(\%$ change in quantity) / (\% change in price)

Total revenue $=\mathrm{PQ}$, as $\mathrm{P}$ changes total revenue will depend on elasticities

$\mathrm{e}_{\mathrm{d}}>1$, elastic, PQ and P move in opposite directions, and BOP will improve.

$<1$, inelastic, PQ and P move in same directions, BOP will become worsen.

= 1 , unit elastic, PQ unaffected by $\mathrm{P}, \mathrm{BOP}$ will remain unaffected.

\section{Appendix-2}

\section{Absorption Approach to the Balance of Trade}

Trade balance is difference between what the economy produces and what it spends (absorbs)

If $\mathrm{Y}=\mathrm{C}+\mathrm{I}+\mathrm{G}+(\mathrm{X}-\mathrm{M})$

then $(\mathrm{X}-\mathrm{M})=\mathrm{Y}-(\mathrm{C}+\mathrm{I}+\mathrm{G})$

A surplus country produces more than it absorbs and deficit country produces less than its absorption.

A devaluation of the domestic currency when there is unemployment may stimulate production and increase the trade surplus or reduce the deficit. Devaluation with full employment will create inflation as foreigners increase demand for domestic goods but no more can be produced in the short run. 


\section{Appendix-3}

\section{Monetary Approach to the Balance of Payments}

Balance of payments flows have implications for money supplies.

1. With fixed exchange rates, money will flow between countries and prices will change to maintain equilibrium.

Draw the line in the balance of payments so only official monetary transactions are below the line and we have the impact of the balance of payments on international reserves.

2. International reserves are part of base money-the base for expansion of the money supply.

\section{A Simple MABP Model:}

$$
\mathrm{L}=\mathrm{kPY}
$$

where $\mathrm{L}$ is money demand, $\mathrm{k}$ is fraction of national income held as money, $\mathrm{P}$ is the price level and $\mathrm{Y}$ is real GDP.

$$
\mathrm{M}=\mathrm{R}+\mathrm{D}
$$

where $\mathrm{M}$ is money supply, $\mathrm{R}$ is international reserves and $\mathrm{D}$ is domestic credit.

$$
\mathrm{P}=\mathrm{EP}^{\mathrm{F}}
$$

where $\mathrm{P}$ is domestic price level, $\mathrm{E}$ is exchange rate and $\mathrm{P}^{\mathrm{F}}$ is foreign price level.

Putting equation (3) in equation (1) and equating to equation (2) as at equilibrium money demand will be equal to money supply.

$$
\begin{aligned}
& \mathrm{L}=\mathrm{M} \\
& \mathrm{L}=\mathrm{kEP}^{\mathrm{F}} \mathrm{Y} \\
& \mathrm{kEP}^{\mathrm{F}} \mathrm{Y}=\mathrm{R}+\mathrm{D}
\end{aligned}
$$

In percentage changes form equation (4) can be written as

$$
\hat{E}+\hat{P}^{F}+\hat{Y}=\hat{R}+\hat{D}
$$


Under the fixed exchange rate equation (4) can be:

$$
\hat{R}=\hat{P}^{F}+\hat{Y}-\hat{D}
$$

And with managed float exchange rate:

$$
\hat{R}-\hat{E}=\hat{P}^{F}+\hat{Y}-\hat{D}
$$

- Monetary policy causes reserve outflows or BOP deficits.

- A country will eventually run out of reserves to support such a deficit and a devaluation of the exchange rate will occur.

- Can cure a BOP deficit by restrictive monetary policy rather than exchange rate change-devaluation is a substitute for reducing money growth.

- Higher domestic income is associated with improvement in the BOP. 


\section{References}

Alexander, S.S. (1952). Effects of a Devaluation on a Trade Balance. International Monetary Fund Staff Papers, 2, 263-278.

Alexander, S.S. (1959). Effects of a Devaluation: A Simplified Synthesis of Elasticities and Absorption Approaches. American Economic Review, 49, 21-42.

Bahmani-Oskooee, M. (1991). Is There a Long-Run Relation Between the Trade Balance and the Real Effective Exchange Rate of LDCs? Economic Letters, 403-407.

Bahmani-Oskooee, M. (2001). Nominal and Real Effective Exchange Rates of Middle Eastern Countries and Their Trade Performance. Applied Economics, 33, 103-111.

Bahmani-Oskooee, M., and Brooks, T.J. (1999). Bilateral J-Curve Between US and Her Trading Partners. Weltwirtschaftliches Archiv, 135, 156-165.

Bahmani-Oskooee, M., and Niroomand, F. (1998). Long-Run Price Elasticities and the Marshall Lerner Condition Revisited. Economics Letters, 61, 101-9.

Bahmani-Oskooee, M., and Ratha, A. (2004). The J-Curve: A Literature Review. Applied Economics, 36, 1377-98.

Bickerdike, C.F. (1920). The Instability of Foreign Exchanges. The Economic Journal.

Duasa, J. (2007). Determinants of Malaysian Trade Balance: An ARDL Bound Testing Approach. Journal of Economic Cooperation, 28(3), 21-40.

Edwards, S. (2002). Capital Mobility, Capital Controls, and Globalization in the Twenty First Century. The Annals of the American Academy of Political and Social Science, 579, 261-70.

Goldstein, M. (1992). Mechanisms for Promoting Global Monetary Stability. In Policy Issues in the Evolving, International Monetary System. Washington DC, IMF Occasional Paper, 26.

Gomes, F.A.R., and Paz, L.S. (2005). Can Real Exchange Rate Devaluation Improve Trade Balance? The 1990-1998 Brazilian Case. Applied Economics Letters, 12, 525-8. 
Greenwood, J. (1984). Non-Traded Goods, the Trade Balance and the Balance of Payments. Canadian Journal of Economics, 17, 806-823.

Hahn, F.H. (1959). The Balance of Payments in a Monetary Economy. Review of Economic Studies, 26, 110-125.

Harberger, A.C. (1950). Currency Depreciation, Income and the Balance of Trade. Journal of Political Economy, 58, 47-60.

Himarios, D. (1989). Devaluations Improve the Trade Balance? The Evidence Revisited. Economic Inquiry, 143-168.

La1, A.K., and Lowinger, T.C. (2001). J-Curve: Evidence from East Asia. Manuscript presented at the $40^{\text {th }}$ Annual Meeting of the Western Regional Science Association, February 2001 in Palm Springs, CA.

Liew, K.S., Lim, K.P., and Hussain, H. (2003). Exchange Rates and Trade Balance Relationship: The Experience of ASEAN Countries. International Trade. 0307003, Econ WPA.

Lutkepoh1, H. (1991). Introduction to Multiple Time Series Analysis. Berlin, Springer-Varlag.

Mahdavi, S., and Sohrabian, A. (1993). The Exchange Value of the Dollar and the US Trade Balance: An Empirical Investigation Based on Cointegration and Granger Causality Tests. Quarterly Review of Economics and Finance, 33, 343-358.

Mahmud, S.F., et a1. (2004). Testing Marshall Lerner Condition: a NonParametric Approach. Applied Economics Letters, 11, 231-236.

Meade, J.E. (1951). The Balance of Payments, Oxford: University Press.

Metzler, L. (1948). A Survey of Contemporary Economics, Vol. I. Richard D. Irwin, INC, Homewood, IL.

Miles, M.A. (1979). The Effects of Devaluation on the Trade Balance and the Balance of Payments: Some New Results. Journal of Political Economy, 87(3), 600-20.

Mundell, R.A. (1968). International Economics. NY: Macmillan.

Mundell, R.A. (1971). Monetary Theory. Pacific Palisades: Goodyear. 
Mussa, M. (2002). Exchange Rate Regimes in an Increasingly Integrated World Economy. Washington D.C.

Narayan, P.K. (2004). Reformulating Critical Values for the Bounds FStatistics Approach to Cointegration: An Application to the Tourism Demand Model for Fiji. Discussion Papers, Department of Economics, Monash University, Australia.

Onafowora, O. (2003). Exchange Rate and Trade Balance in East Asia: Is There a J-Curve? Economic Bulletin, 5(18), 1-13.

Pearce, I.F. (1961). The Problem of the Balance of Payments. International Economic Review, 2, 1-28.

Pesaran, H.M. (1997). The Role of Economic Theory in Modelling the LongRun. Economic Journal, 107, 178-191.

Pesaran, H.M., and Shin, Y. (1995). Autoregressive Distributed Lag Modelling Approach to Cointegration Analysis. DAE Working Paper Series No. 9514, Department of Applied Economics, University of Cambridge.

Pesaran, H.M., and Shin, Y. (1999). Autoregressive Distributed Lag Modelling Approach to Cointegration Analysis, Chapter 11, in Storm, S., (ed.), Econometrics and Economic Theory in the $20^{\text {th }}$. Century: The Ragnar Frisch Centennial Symposium. Cambridge University Press: Cambridge.

Pesaran, H.M., and Pesaran, B. (1997). Microfit 4.0: Interactive Econometric Analysis. Oxford University Press: England.

Pesaran, H.M., Shin, Y. and Smith, R. (1996). Testing the Existence of a Long-Run Relationship. DAE Working Paper Series No. 9622, Department of Applied Economics, University of Cambridge.

Pesaran, H.M., Shin, Y. and Smith, R.J. (2001). Bounds Testing Approaches to the Analysis of Level Relationships. Journal of Applied Econometrics, 16, 289-326.

Polak, J.J. (1957). Monetary Analysis on Income Formation and Payments Problems. International Monetary Fund Staff Papers, 6, 1-50. 
Prais, S.J. (1961). Some Mathematical Notes on the Quantity Theory of Money in a Small Open Economy. International Monetary Fund Staff Papers, 2, 212-226.

Rahman, M. and Mustafa, M. (1996). The Dancing of the Real Exchange Rate of US Dollar and the US Real Trade Balance. Applied Economics Letters, 3, 807-808.

Rahman, M., Mustafa, M. and Burckel, D.V. (1997). Dynamics of the YenDollar Real Exchange Rates and the US-Japan Real Trade Balance. Applied Economics, 29, 661-664.

Robinson, J. (1947). Essays in the Theory of Employment. Oxford: Basil Blackwell.

Rose, A.K., and Yellen, J.L. (1989). In there a J-Curve? Journal of Monetary Economics, 24, 53-68.

Rose, A.K. (1991). The Role of Exchange Rate in a Popular Model of International Trade: Does the Marshall Lerner Condition Hold? Journal of International Economics, 30, 301-316.

Rose, A.K. (1990). Exchange Rates and the Trade Balance: Some Evidence from Developing Countries. Economics Letters, 34, 271-75.

Sims, C.A. (1980). Macroeconomics and Reality. Econometrica, 48, 1-48.

Singh, T. (2002). India's Trade Balance: The Role of Income and Exchange Rates. Journal of Policy Modeling, 24, 437-452.

Tavlas, S. (2003). The Economics of Exchange Rate Regimes: A Review Essay. Oxford: Blackwell Publishing Ltd.

Tsen, W.H. (2006). Is There a Long Run Relationship between Trade Balance and Terms of Trade? The Case of Malaysia. Applied Economics Letters, 13,307-11. 